\title{
Analyzing the production chemistry data of the North Sea chalk reservoirs with a multiphase reactive transport model
}

Taheriotaghsara, Mirhossein; Bonto, Maria; Eftekhari, Ali A.; M. Nick, Hamid

Publication date:

2019

Document Version

Publisher's PDF, also known as Version of record

Link back to DTU Orbit

Citation (APA):

Taheriotaghsara, M., Bonto, M., Eftekhari, A. A., \& M. Nick, H. (2019). Analyzing the production chemistry data of the North Sea chalk reservoirs with a multiphase reactive transport model. Abstract from Danish Hydrocarbon Research and Technology Centre

Technology Conference 2019, Kolding, Denmark.

\section{General rights}

Copyright and moral rights for the publications made accessible in the public portal are retained by the authors and/or other copyright owners and it is a condition of accessing publications that users recognise and abide by the legal requirements associated with these rights.

- Users may download and print one copy of any publication from the public portal for the purpose of private study or research.

- You may not further distribute the material or use it for any profit-making activity or commercial gain

- You may freely distribute the URL identifying the publication in the public portal 


\section{Danish Hydrocarbon Research and Technology Centre \\ Technology Conference 2019}

\section{Analyzing the production chemistry data of the North Sea chalk reservoirs with a multiphase reactive transport model}

Mirhossein Taheriotaghsara, Maria Bonto, Ali A. Eftekhari, Hamid M. Nick

Ali A. Eftekhari

Is the presenting author a research assistant/MSc/PhD student/Postdoc? No

AWF1

Production chemistry contains a wealth of data that describes the physico-chemical interactions between the injected water, formation water, crude oil, and reservoir rock. By combining a tuned surface complexation model for oil-brine and chalk-brine, a two-phase flow model, and published 4D seismic data, we try to explain the production chemistry data from a production well in the Halfdan field. 